\title{
Preparation, Characterization, and Application of Manganese Oxide Coated Zeolite as Adsorbent for Removal of Copper(II) Ions from Seawater
}

\author{
Mohamed A. Shreadah1, Omnia Gamal Abdel Hamid1, Amr A. Yakout ${ }^{2,3}$, \\ Ramadan H. El-Sokkary 3 \\ ${ }^{1}$ National Institute of Oceanography and Fisheries, Alexandria, Egypt \\ ${ }^{2}$ ChemistryDepartment, Faculty of Science, University of Jeddah, Jeddah, KSA \\ ${ }^{3}$ Chemistry Department, Faculty of Science, Alexandria University, Alexandria, Egypt \\ Email: niof.shreadah@gmail.com
}

How to cite this paper: Shreadah, M.A., Hamid, O.G.A., Yakout, A.A. and El-Sokkary, R.H. (2019) Preparation, Characterization, and Application of Manganese Oxide Coated Zeolite as Adsorbent for Removal of Copper (II) Ions from Seawater. Journal of Environmental Protection, 10, 1262-1277. https://doi.org/10.4236/jep.2019.1010075

Received: August 2, 2019

Accepted: October 7, 2019

Published: October 10, 2019

Copyright $\odot 2019$ by author(s) and Scientific Research Publishing Inc. This work is licensed under the Creative Commons Attribution International License (CC BY 4.0).

http://creativecommons.org/licenses/by/4.0/

(c) (i) Open Access

\begin{abstract}
The present study is aimed to examine the adsorption characteristics of $\mathrm{Cu}$ (II) by using the novel cellulose acetate composite and to apply it for the removal of $\mathrm{Cu}$ (II) from real wastewater samples. In order to achieve this objective, ethylenediamine, diethylenetriamine, triethylenetetramine and tetraethylenepentanene were used for immobilization of grafted cellulose acetate-nanoscale manganese dioxide. Cellulose was extracted from mangrove species Avicennia marina and converted to cellulose acetate then it was formed composite with nano-manganese dioxide via precipitation of nano-manganese dioxide on it. The composite was grafted with acrylamide monomer before immobilization. The synthesized compounds were used for adsorption of $\mathrm{Cu}(\mathrm{II})$ and characterized by FT-IR, TGA and SEM. The adsorption characteristics of synthesized sorbents were optimized. Langmuir and Freundlich models were used to establish sorption equilibria. The analytical applications of these modified materials were applied successfully for the removal of $\mathrm{Cu}(\mathrm{II})$.
\end{abstract}

\section{Keywords}

Manganese Oxide Coated Zeolite, Removal of Copper(II) Ions, Seawater

\section{Introduction}

There has been an increasing ecological and global public health concern asso- 
ciated with environmental contamination by heavy metals as they may pose risks and hazards to humans [1]-[10] because of their toxicity, persistence and bioaccumulation in food chain [11] [12] [13]. It is normally encountered in industrial wastewater of many industries such as electrical, electroplating, paper manufacturing, pesticides, herbicides and tannery industries. The continuous intake of copper by human beings leads to necrotic changes in the liver and kidney, mucosal irritation; wide-spread capillary damage, depression, weakness, lethargy, anorexia, gastrointestinal irritation and lung cancer [14] [15] [16]. Various methods are used for extraction of heavy metals from aqueous solution, such as reverse osmosis, chemical precipitation, ion exchange, coagulants and flocculation and adsorption [17] [18] [19] [20]. Most of these methods do not seem to be economically feasible because of their relatively high cost. However, the adsorption technique by solid adsorbents is one of the most efficient methods for the wastewater treatment, which exhibits advantages more than the other methods because of simple design and low initial cost [21]. Cellulose is the most abundant organic polymer, environmental-friendly material and has low cost. However, it has low efficiency toward adsorption of heavy metals [20]. One of the cellulose modifications is grafting with certain monomer [22]-[27]. Formation of composite with nano-metal oxides is also another method to improve cellulose efficiency. Iron and manganese oxides nano-particals were mixed with carboxymethyl cellulose [28], also alumina improved properties of cellulose acetate membrane [29]. Titanium oxide nano-particales were added into cellulose acetate membrane which can lead to improvement of membrane porosity, stability and performance [30]. Cellulose-nanoscale-manganese oxide composite was in situ prepared to remove $\mathrm{Pb}(\mathrm{II})$ from water [31].

In the present work, cellulose is isolated from mangrove trees (Avicennia marina) in Safaga. The extracted cellulose was acetylated and modified by forming composite with $\mathrm{NMO}$ followed by grafting copolymerization with acrylamide. The grafted cellulose acetate copolymer-nano manganese oxide composite was functionalized with ethylenediamine, diethylenetriamine, triethylenetetramine and tetraethylenepentanene for higher metal loading. The adsorption characteristics of the novel cellulose acetate composite towards $\mathrm{Cu}(\mathrm{II})$ were studied. Finally, the functionalized composite was successfully employed in the recovery of the mentioned metal ion from real wastewater samples.

\section{Material and Methods}

\section{Chemicals}

Acrylamide $\left(\mathrm{C}_{3} \mathrm{H}_{5} \mathrm{NO}, \mathrm{M}_{W}=71.08\right)$, tetraethylenepentamine $\left(\mathrm{C}_{8} \mathrm{H}_{23} \mathrm{~N}_{5}, \mathrm{M}_{W}=\right.$ 189.3) and acetic anhydride were purchased from sigma. Ethylenediamine $\left(\mathrm{C}_{2} \mathrm{H}_{8} \mathrm{~N}_{2}, \mathrm{M}_{W}=60.1\right)$ was purcused from Loba Chemie. Diethylenetriamine $\left(\mathrm{C}_{4} \mathrm{H}_{13} \mathrm{~N}_{3}, \mathrm{M}_{W}=103.2\right)$ was purchased from Alph Aeser. Triethylenetetramine $\left(\mathrm{C}_{6} \mathrm{H}_{18} \mathrm{~N}_{4}, \mathrm{M}_{W}=146.2\right)$ was purchased from $\mathrm{BDH}$, UK. Potassium permanganate $\left(\mathrm{KMnO}_{4}, \mathrm{M}_{W}=158.03\right.$, with assay $\left.=99.1 \%\right)$ and copper chloride $\left(\mathrm{CuCl}_{2} \cdot 2 \mathrm{H}_{2} \mathrm{O}\right.$, FW 
$=170.48$, with assay $=98.0 \%)$ were purchased from United Company, Egypt. Disodium salt ethylenediamine tetraacetate dehydrate (EDTA) $\left(\mathrm{C}_{10} \mathrm{H}_{14} \mathrm{~N}_{2} \mathrm{Na}_{2} \mathrm{O}_{8} \cdot 2 \mathrm{H}_{2} \mathrm{O}\right.$, $\mathrm{M}_{W}=372.24$, with assay $\left.=99.0 \%-100.0 \%\right)$ was purchased from Riedel-de Haën.

Collecting of mangrove Avicennia marina and Extraction of cellulose from its roots pulp

Mangrove species Avicennia marina was collected from Safaga coast in Egyptian Red sea $\left(26^{\circ} 44^{\prime} 0^{\prime \prime} \mathrm{N} / 33^{\circ} 56^{\prime} 0^{\prime \prime} \mathrm{E}\right)$. The solid impurities were removed by washing with water and the roots were dried in air and manually separated its pulp. Then it was ground in a rotating ball mill. $50.0 \mathrm{~g}$ of dried mangrove Avicennia marina roots pulp powder was treated with $8 \%(\mathrm{v} / \mathrm{v}) \mathrm{NaOH}$ solution for 2 $\mathrm{h}$ at $80^{\circ} \mathrm{C}$. After the treatment, the slurry was washed with warm water and filtered then neutralized using a solution of $2 \%(\mathrm{v} / \mathrm{v})$ acetic acid [32]. The powder was stirred in $250.0 \mathrm{ml}$ commercial hypochlorite at $\mathrm{pH} 10$ for $1 \mathrm{~h}$, then in 125.0 $\mathrm{ml}$ commercial hypochlorite at $\mathrm{pH} 6$ for $1 \mathrm{~h}$, finally in $3.5 \% \mathrm{H}_{2} \mathrm{O}_{2}$ for $1 \mathrm{~h}$. The bleached cellulose was filtered and washed with distilled water then dried at room temperature [31].

Preparation of cellulose acetate-nano-manganese dioxide hybrid material (CA-NMO)

In the first, cellulose was acetylated by adding $1.5 \mathrm{~g}$ of cellulose in a mixture of $7.5 \mathrm{ml}$ of acetic anhydride and $0.015 \mathrm{~mL}$ of sulphuric acid $98 \mathrm{wt} \%$ (used as a catalyst) and vigorously stirred at $30^{\circ} \mathrm{C}$ for 1 hour. The mixture was poured into a large volume of water, and the precipitate was formed. It was filtered through Buckner funnel, washed to neutrality and dried in air. ${ }^{28}$ Secondly, cellulose acetate-manganese dioxide composites were prepared by impregnating $1.0 \mathrm{~g} \mathrm{CA}$ into $500.0 \mathrm{ml} \mathrm{KMnO}_{4}$ solution $(1.0 \mathrm{~g} / 500.0 \mathrm{ml}$ distilled water) for $15 \mathrm{~min}$. $\mathrm{KMnO}_{4}$ impregnated cellulose acetate was subsequently reduced by adding 10.0 $\mathrm{ml}$ ethanol drop by drop under stirring till color change to brown. The reaction mixture was kept at rest for two hours. The composites were filtered then washed with distilled water and dried at $60^{\circ} \mathrm{C}$ [31] (Scheme 1).

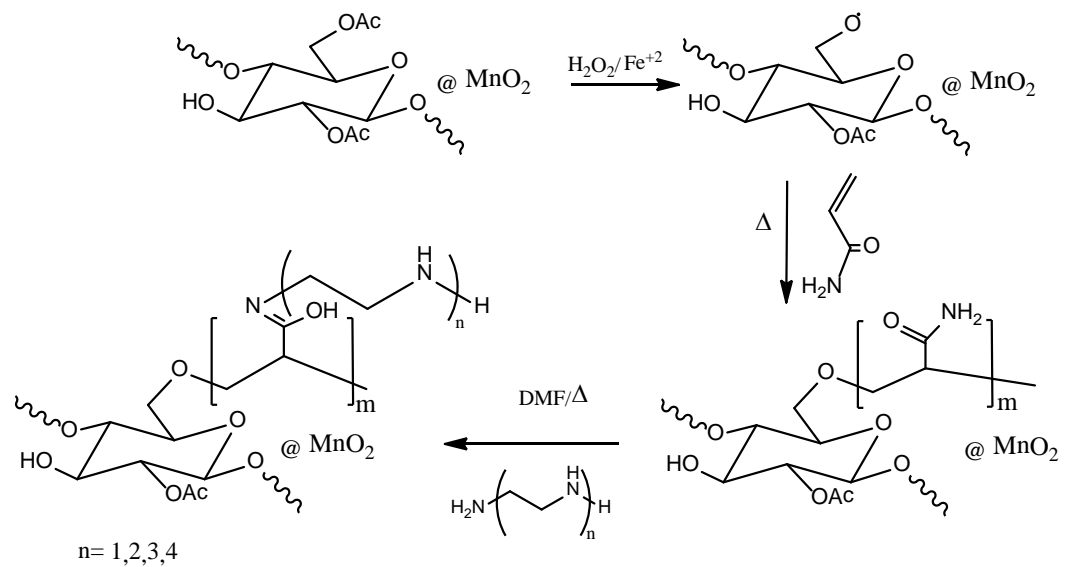

Scheme 1. Preparation of immobilized cellulose acetate composite analogs. 
Grafting copolymerization of cellulose acetate-manganese dioxide composites (g-CA-NMO)

$2.0 \mathrm{~g}$ of CA-NMO were mixed with $8.0 \mathrm{ml}$ of ferrous ammonium sulfate $(0.02$ $\mathrm{M})$ which transferred into a reaction flask equipped with stirring. The suspension was allowed to stir for $15 \mathrm{~min}$ at $30^{\circ} \mathrm{C}$. To the mixture $12 \mathrm{ml}$ of $\mathrm{H}_{2} \mathrm{O}_{2}(0.2$ $\mathrm{M})$ were added with stirring $5 \mathrm{~min}$ at the same temperature. The polymerization was started by adding $5.0 \mathrm{~g}$ acrylamide. The reaction mixture was stirred at $80^{\circ} \mathrm{C}$ for $4 \mathrm{~h}$. Graft copolymer (g-CA-NMO) was recovered by filtration, washed with hot water and finally dried at room temperature [30].

\section{Immobilization of (g-CA-NMO) with ethylenediamine}

The modified cellulose acetate obtained in the above step g-CA-NMO was immobilized by ethylenediamine when $2.0 \mathrm{~g}$ of g-CA-NMO was suspended in $1.5 \mathrm{ml}$ of amine and $12.0 \mathrm{ml}$ DMF. The reaction mixture was heated up to $75^{\circ} \mathrm{C}$ $80^{\circ} \mathrm{C}$ for $10 \mathrm{~h}$ on a water bath [32] [33]. The product obtained was filtered off, washed with methanol, dried in air and referred as (g-CA-EN-NMO).

\section{Immobilization of (g-CA-NMO) with diethylenetriamine}

The modified cellulose acetate obtained in the above step g-CA-NMO was immobilized by diethylenetriamine when $2.0 \mathrm{~g}$ of g-CA-NMO was suspended in $2.2 \mathrm{ml}$ of amine and $12.0 \mathrm{ml}$ DMF. The reaction mixture was heated up to $75^{\circ} \mathrm{C}$ $80^{\circ} \mathrm{C}$ for $24 \mathrm{~h}$ on a water bath [33] [34] [35]. The product obtained was filtered off, washed with methanol, dried in air and referred as (g-CA-DETA-NMO).

\section{Immobilization of (g-CA-NMO) with triethylenetetramine}

The modified cellulose acetate obtained in the above step g-CA-NMO was immobilized by triaethylenetetramine when $2.0 \mathrm{~g}$ of g-CA-NMO was suspended in $3.0 \mathrm{ml}$ of amine and $12.0 \mathrm{ml}$ DMF. The reaction mixture was heated up to $75^{\circ} \mathrm{C}-80^{\circ} \mathrm{C}$ for $24 \mathrm{~h}$ on a water bath [33] [34] [35]. The product obtained was filtered off, washed with methanol, dried in air and referred as (g-CA-TETA-NMO).

\section{Immobilization of (g-CA-NMO) with tetraethylenepentamine}

The modified cellulose acetate obtained in the above step g-CA-NMO was immobilized by tetraethylenepentamine when $2.0 \mathrm{~g}$ of g-CA-NMO was suspended in $5.0 \mathrm{ml}$ of amine and $12.0 \mathrm{ml}$ DMF. The reaction mixture was heated up to $75^{\circ} \mathrm{C}-80^{\circ} \mathrm{C}$ for $72 \mathrm{~h}$ on a water bath [33] [34] [35]. The product obtained was filtered off, washed with methanol, dried in air and referred as (g-CA-TEPA-NMO).

\section{Adsorption studies}

All batch sorption experiments were carried out at room temperature $\left(25^{\circ} \mathrm{C} \pm\right.$ $1^{\circ} \mathrm{C}$ ). Each experiment was performed in $50 \mathrm{~mL}$ volumetric flask by mixing a 1.0 $\mathrm{ml}$ of $0.1 \mathrm{~mol} \cdot \mathrm{l}^{-1}$ metal ion solution with $100 \pm 1 \mathrm{mg}$ of the dry sorbent and the $\mathrm{pH}$ was adjusted by adding $9.0 \mathrm{ml}$ of buffer solutions ( $\mathrm{pH} 1.0-7.0$ ). This mixture was shaken by using an automatic shaker for $30 \mathrm{~min}$ then filtered and washed with $50 \mathrm{ml}$ of distilled water. The residual metal ion content in the filtrate was determined and each experiment was repeated three times. The previously mentioned batch experiment procedure was carried out at different 
shaking time of $1,5,10,15,20,25,30,35,40,45,50,55$ and $60 \mathrm{~min}$ and optimum buffering condition ( $\mathrm{pH} 7.0$ ).

In each batch experiment, the sorption metal capacity value was calculated from a metal mass balance (Equation (1)).

$$
q=\frac{\left(C_{o}-C\right) V}{m}
$$

where, $C_{\mathrm{o}}$ and $C\left(\mathrm{~mol} \cdot \mathrm{l}^{-1}\right)$ are the initial and residual metal ion concentration respectively, $V(\mathrm{l})$ is the volume of the solution, $m(\mathrm{~g})$ is the mass of dry sorbent and $q\left(\mathrm{mmol} \cdot \mathrm{g}^{-1}\right)$ is the sorption metal capacity.

Similar batch experiments were carried out by mixing a $1.0 \mathrm{~mL}$ of $0.1 \mathrm{~mol} \cdot \mathrm{l}^{-1}$ metal ion solutions with $9.0 \mathrm{ml}$ of buffer solution ( $\mathrm{pH} 7.0$ ) and by using different sorbent masses of 5.0, 10.0, 20.0, 40.0, 60.0, 80.0, 100.0, 200.0 and $250.0 \mathrm{mg}$. The sorption mixture was shaken for $30 \mathrm{~min}$ and the percentages of metal removal were then determined in the residual metal ion content in the filtrate.

Sorption equilibrium and isotherm studies were evaluated by varying the initial metal ion volume. A $0.1 \mathrm{M}$ solution of $0.6,0.8,1.0,1.2,1.4$, and $1.6 \mathrm{ml}$ metal ion was used. This solution was mixed with $9.0 \mathrm{~mL}$ of buffer $\mathrm{pH} 7.0$ and $100 \pm 1$ $\mathrm{mg}$ of the dry sorbent and shaken for $30 \mathrm{~min}$. The mixture was filtered and washed with $50 \mathrm{ml}$ of distilled water.

\section{Extraction of $\mathrm{Cu}$ (II) ion from real hard water samples}

Three different water samples were examined for removal of $\mathrm{Cu}$ (II) by the sorbents. The first sample is drinking tap water, the second was obtained from Mediterranean seawater at Alexandria, Egypt and the third is industrial wastewater sample was collected from Al-Nubariya canal. These water samples were spiked with $1 \mathrm{ppm}$ of the selected metal ion. A $1.0 \mathrm{l}$ of water sample was passed over a micro-column system packed with $100 \pm 1.0 \mathrm{mg}$ of sorbent by using a flow rate of $10 \mathrm{ml} \cdot \mathrm{min}^{-1}$ under air pressure [35]. Effluent solution was collected and subjected to metal determination by atomic absorption analysis. This procedure was repeated three times.

\section{Instrumentations}

FT-IR spectra were recorded on a Burker Tensor 37 FTIR between 4000 and $400 \mathrm{~cm}^{-1}$. Thermogravimetric analyses (TGA) were caried out in a nitrogen atmosphere using Perkin-Elmer TGA7 Thermobalance. The flow rate of $\mathrm{N}_{2}$ was adjusted at $20 \mathrm{ml} / \mathrm{min}$ and heating rat was $10^{\circ} \mathrm{C} / \mathrm{min}$. Scanning electron microscope (SEM) was performed using FEI Quanta 250. SHIMADZU atomic absorption spectrophotometer (AAS) AA-6800 was used to determine metal ions concentrations.

\section{Results and Discussion}

\section{Characterization and surface morphology}

FT-IR spectra of cellulose, CA, g-CA-NMO, g-CA-EN-NMO, g-CADETA-NMO, g-CA-TETA-NMO and g-CA-TEPA-NMO are shown in (Figure 1). There are two differences between the spectrum of cellulose and CA (Figure 1 curve a, b, respectively) which proves acetylation of extracted cellulose, the 
first one is the decrease in intensity of $\mathrm{OH}$ peak at $3444 \mathrm{~cm}^{-1}$ in CA compared to that of cellulose which was at $3407 \mathrm{~cm}^{-1}$. The second evidence is the presence of three important ester bands at $1752 \mathrm{~cm}^{-1}\left(\mathrm{C}=\mathrm{O}\right.$ ester), $1378 \mathrm{~cm}^{-1}$ (C-H bond in $-\mathrm{O}(\mathrm{C}=\mathrm{O})-\mathrm{CH}_{3}$ group) and $1241 \mathrm{~cm}^{-1}$ (-CO-stretching of acetyl group) in CA. For FT-IR spectra of g-CA-NMO, g-CA-EN-NMO, g-CA-DETA-NMO, g-CA-TETA-NMO and g-CA-TEPA-NMO (Figure 1 curve $c, d, e, f, g$, respectively), the broad bands of hydrogen bonding of $\mathrm{OH}$ groups are shown at 3420 , $3400,3410,3420$ and $3383 \mathrm{~cm}^{-1}$, respectively, but the $\mathrm{N}-\mathrm{H}$ band in g-CA-EN-NMO, g-CA-DETA-NMO, g-CA-TETA-NMO and g-CA-TEPANMO cannot be detected due to its overlapping with the broad $\mathrm{OH}$ band.

The spectrum of g-CA-NMO (Figure 1 curve $c$ ) exhibits a little shift in $\mathrm{C}=\mathrm{O}$ peak compared to that of in CA spectrum from $1752 \mathrm{~cm}^{-1}$ to $1747 \mathrm{~cm}^{-1}$ due to vibrational modes of $\mathrm{C}=\mathrm{O}$ after grafting. For FT-IR spectra of g-CA-EN-NMO, g-CA-DETA-NMO, g-CA-TETA-NMO and g-CA-TEPA-NMO (Figure 1 curve $\mathrm{d}, \mathrm{e}, \mathrm{f}, \mathrm{g}$, respectively), $\mathrm{C}=\mathrm{N}$ bands are detected at 1654, 1656, 1655 and 1651 $\mathrm{cm}^{-1}$, respectively and C-N stretching bands are detected at 1051, 1058, 1059 and $1064 \mathrm{~cm}^{-1}$, respectively. The bands at 507, 509,511, 497 and $522 \mathrm{~cm}^{-1}$ are assigned to $\mathrm{Mn}-\mathrm{O}$ stretching vibrational modes in g-CA-NMO, g-CA-EN-NMO, g-CA-DETA-NMO, g-CA-TETA-NMO and g-CA-TEPA-NMO, respectively. The presence of NMO in the g-CA-NMO, g-CA-EN-NMO, g-CA-DETA-NMO, g-CA-TETA-NMO and g-CA-TEPA-NMO has negligible effects on their spectra bands (29). In addition, the C-H stretching bands at 2907, 2928, 2928, 2960, 2964, 2924 and $2929 \mathrm{~cm}^{-1}$ and scissoring motion of $\mathrm{CH}_{2}$ bending vibration at $1430,1435,1432,1400,1410,1439$ and $1464 \mathrm{~cm}^{-1}$ are characterized for cellulose, CA, g-CA-NMO, g-CA-EN-NMO, g-CA-DETA-NMO, g-CA-TETA-NMO and g-CA-TEPA-NMO, respectively, where, $\beta$-glycosidic linkage in cellulose spectrum was observed at $897 \mathrm{~cm}^{-1}$.

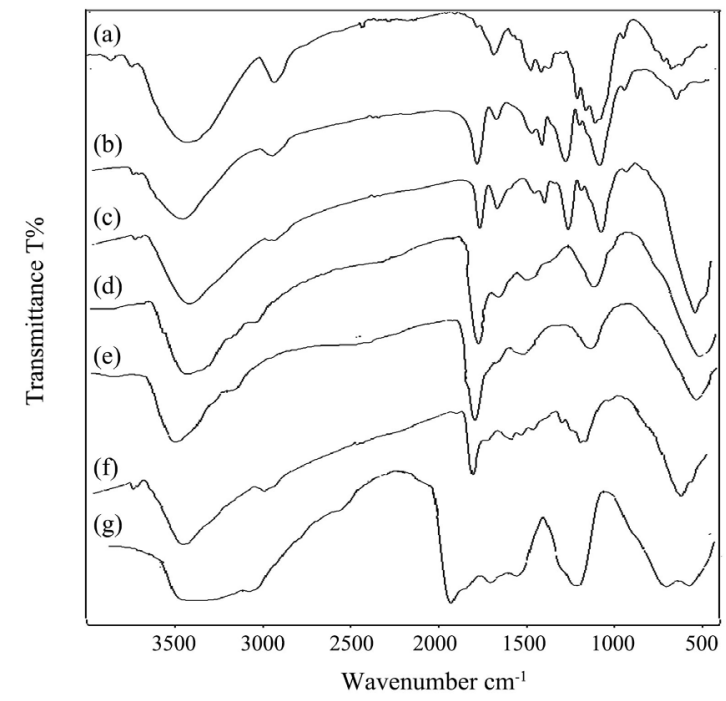

Figure 1. FT-IR spectra of (a) Extracted cellulose, (b) CA, (c) g-CA-NMO, (d) g-CA-EN-NMO, (e) g-CA-DETA-NMO, (f) g-CA-TETA-NMO and (g) g-CA-TEPA-NMO. 
TGA analysis for g-CA-EN-NMO, g-CA-DETA-NMO, g-CA-TETA-NMO and g-CA-TEPA-NMO (Figure 2 curve b, c, d, e, respectively) exhibit firstly weight loss which related to the physically and chemically volatilization and desorption of water molecule $22.9 \%$ within temperature range $22^{\circ} \mathrm{C}-183^{\circ} \mathrm{C}, 23.7 \%$ within temperature range $26^{\circ} \mathrm{C}-189^{\circ} \mathrm{C}, 39.9 \%$ within temperature range $20^{\circ} \mathrm{C}$ $163^{\circ} \mathrm{C}$ and $22 \%$ within temperature range $28^{\circ} \mathrm{C}-141^{\circ} \mathrm{C}$, respectively, then decomposition of immobilized grafted cellulose acetate $36.9 \%$ within temperature range $183^{\circ} \mathrm{C}-338^{\circ} \mathrm{C}, 42.1 \%$ within temperature range $189^{\circ} \mathrm{C}-433^{\circ} \mathrm{C}, 19.4 \%$ within temperature range $163^{\circ} \mathrm{C}-425^{\circ} \mathrm{C}$ and $58.4 \%$ within temperature range $141^{\circ} \mathrm{C}-799^{\circ} \mathrm{C}$, respectively, finally constancy refers to the high thermal stability of NMO.

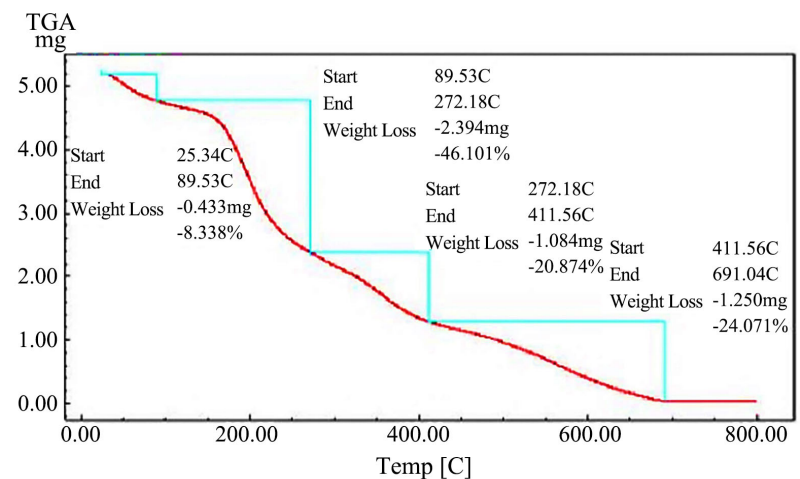

(a)

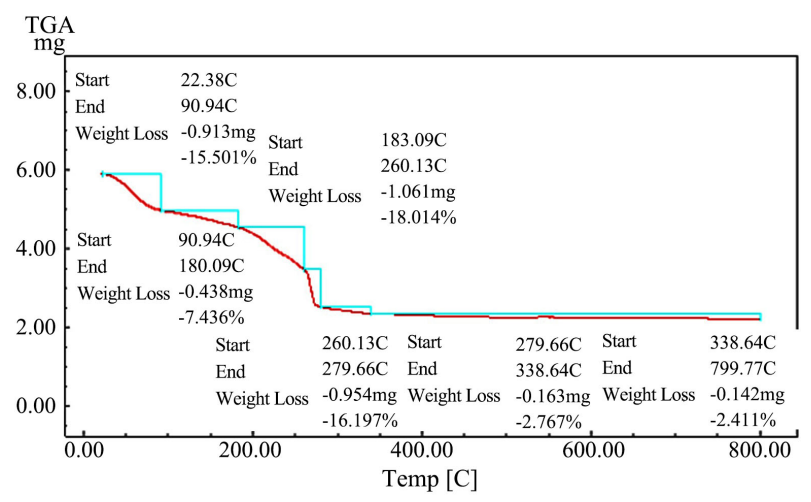

(b)

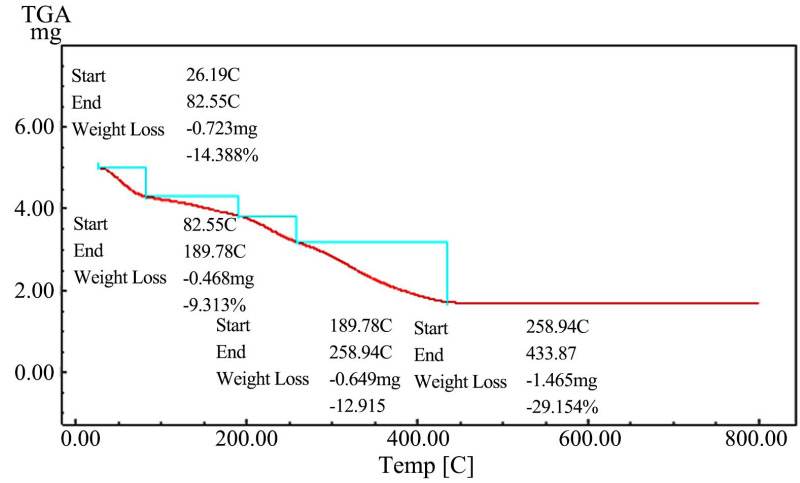

(c) 


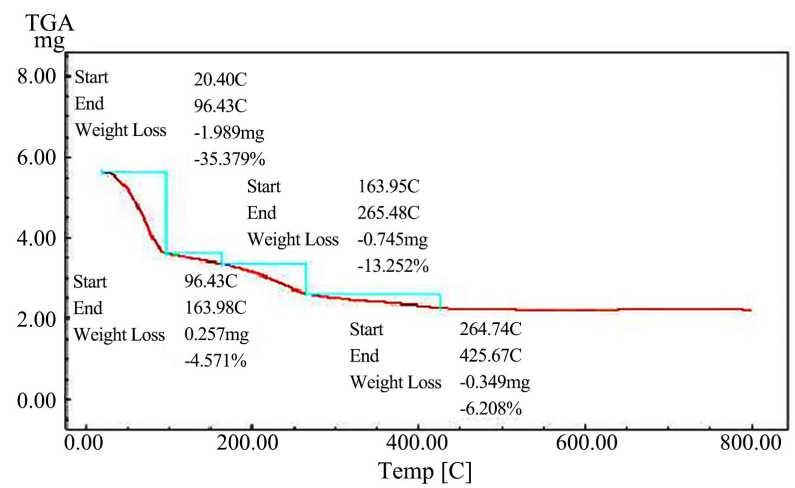

(d)

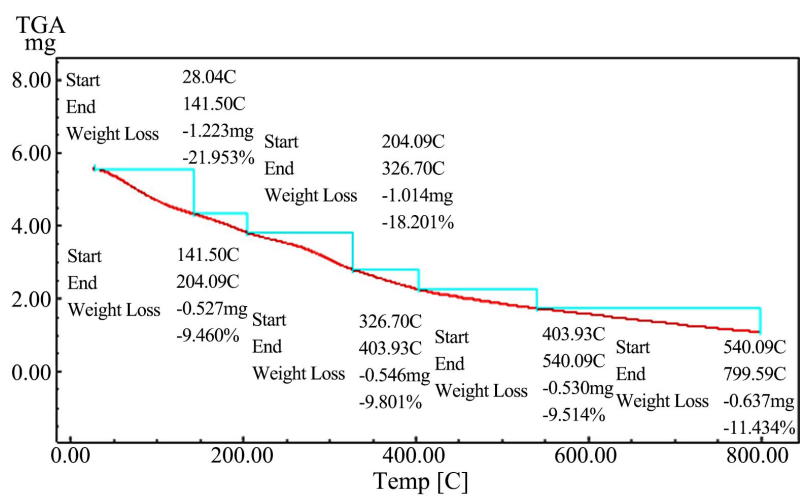

(e)

Figure 2. TGA of (a) CA, (b) g-CA-EN-NMO, (c) g-CA-DETA-NMO, (d) g-CA-TETA-NMO and (e) g-CA-TEPA-NMO.

The SEM images of CA, CA-NMO, g-CA-NMO, g-CA-EN-NMO, g-CADETA-NMO, g-CA-TETA-NMO and g-CA-TEPA-NMO are shown in (Figure 3). SEM images indicate surface morphology of CA upon treatment with NMO loading, grafting copolymerization and immobilization, which clearly showing the presence of similar shiny bulky particles loaded with NMO on its irregular surfaces and indicate homogeneous distribution between them.

\section{Adsorption studies}

\section{Effect of $\mathrm{pH}$}

$\mathrm{pH}$ effect is the most important factor which controls the adsorption process due to its influence on the adsorbent surface, the solution chemistry and the heavy metals. The effect of $\mathrm{pH}$ on the adsorption of $\mathrm{Cu}$ (II) on CA, CA-NMO, g-CA-EN-NMO, g-CA-DETA-NMO, g-CA-TETA-NMO and g-CA-TEPA$\mathrm{NMO}$ at $25^{\circ} \mathrm{C}$ mainly depends on the surface charge of the adsorbents as well as their functional groups (Figure 4). The adsorption capacity is gradually increased as the solution $\mathrm{pH}$ increased and reached their maximum values at $\mathrm{pH} 7$ [36] [37]. At low pH values (1-5), the surface of adsorbents would be surrounded by high concentration of hydronium ions and the functional groups responsible for binding with heavy metal were protonated, so this decrease interaction of the metal ions with binding sites of the adsorbents. As the $\mathrm{pH}$ increased, the overall surface on the adsorbents became negative and adsorbents functional groups are 
deprotonated, so adsorption increased. At $\mathrm{pH}$ values above $\mathrm{pH}$ 5.0, the metals adsorption is indicated by two mechanisms. The first one is the complexation and/or ion-exchange of the metal ions by the deprotonated hydroxyl, amine groups in sorbents. The second mechanism is the adsorption of the metal ions by nano-manganese dioxide in CA-NMO, g-CA-EN-NMO, g-CA-DETA-NMO, g-CA-TETA-NMO and g-CA-TEPA-NMO $(17,18,25)$.

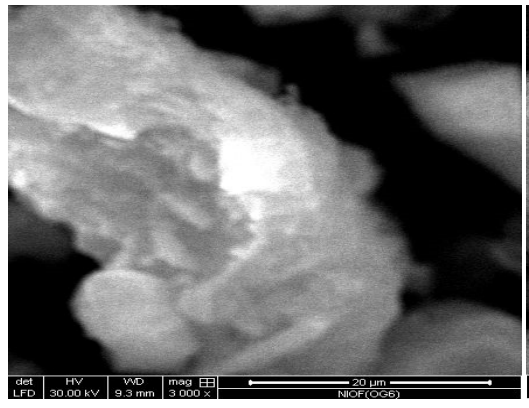

(a)

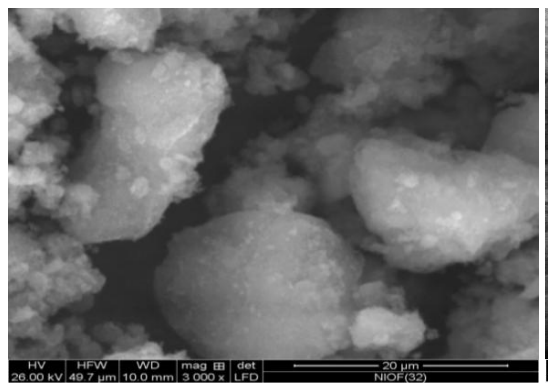

(c)

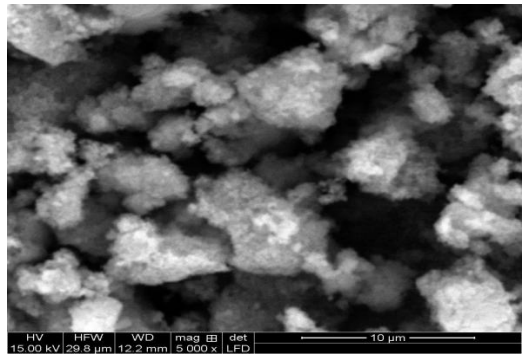

(e)

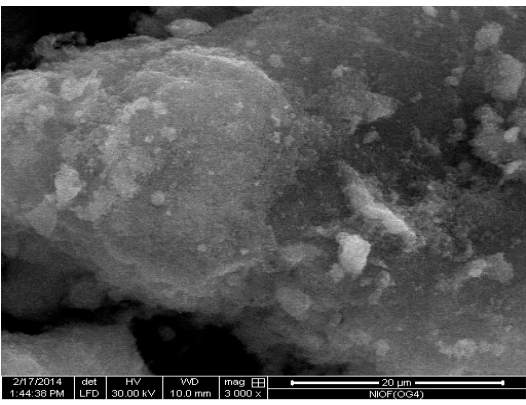

(b)

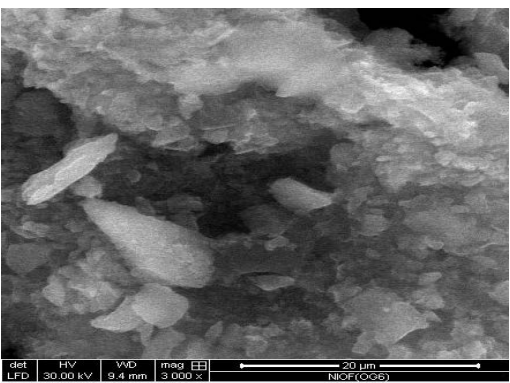

(d)

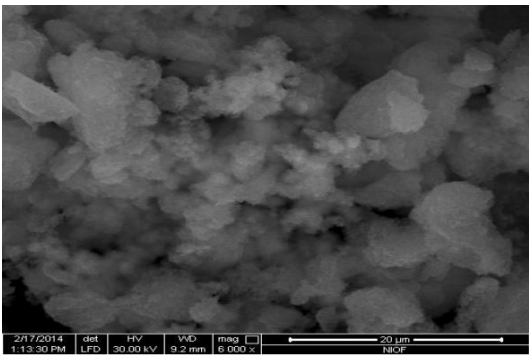

(f)

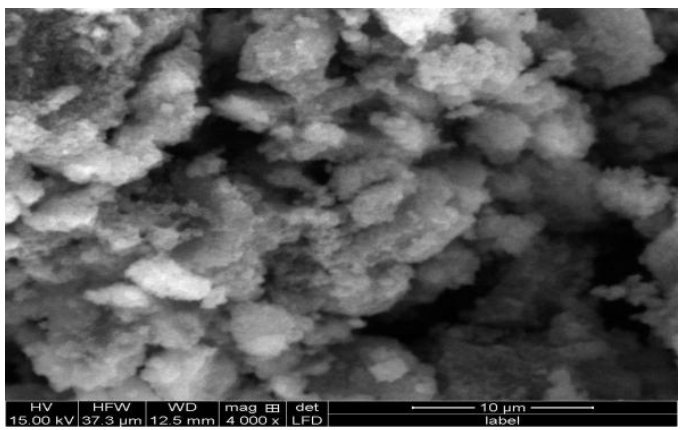

(g)

Figure 3. SEM images of (a) CA, (b) CA-NMO, (c) g-CA-NMO, (d) g-CA-EN-NMO, (e) g-CA-DETA-NMO, (f) g-CA-TETA-NMO and (g) g-CA-TEPA-NMO. 


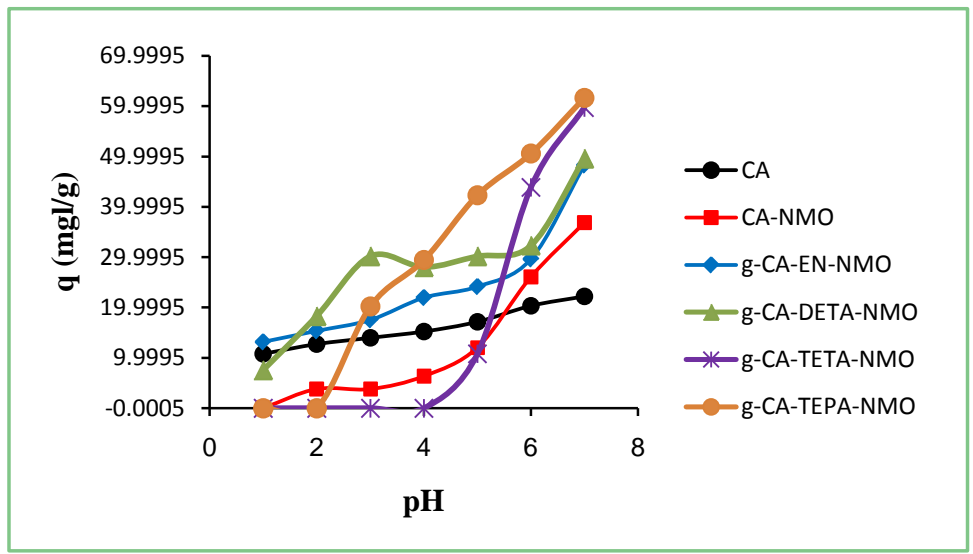

Figure 4. Effect of $\mathrm{pH}$ on the removal of $\mathrm{Cu}(\mathrm{II})$.

\section{Effect of contact time}

The effect of selected shaking time values $(1,5,10,15,20,25,30,40,50$ and 60 min.) on adsorption of $\mathrm{Cu}(\mathrm{II})$ by CA, CA-NMO, g-CA-EN-NMO, g-CADETA-NMO, g-CA-TETA-NMO and g-CA-TEPA-NMO is represented in (Figure 5). The metal capacity values of sorbents for metal ion gradually increased with the increase in shaking time from $1-30 \mathrm{~min}$, where the complete extraction of $\mathrm{Cu}(\mathrm{II})$ ion was obtained above $30 \mathrm{~min}$. The adsorption process becomes less efficient after $30 \mathrm{~min}$ due to complete saturation of the adsorbent surface with the target metal ion. The removal of $\mathrm{Cu}(\mathrm{II})$ ions by $\mathrm{CA}, \mathrm{CA}-\mathrm{NMO}$, g-CA-EN-NMO, g-CA-DETA-NMO, g-CA-TETA-NMO and g-CA-TEPANMO was found to proceed via one adsorption step $(17,18)$.

\section{Effect of sorbent dosage}

The removal of $\mathrm{Cu}$ (II) was studied by varying the sorbent dose of different sorbents (5-250 mg) in aqueous system at $\mathrm{pH}=7$ and $25^{\circ} \mathrm{C}$ as shown in (Figure 6). Increasing sorbent mass the surface area increase as well as greater number of active binding sites and the percentages of extracted $\mathrm{Cu}(\mathrm{II})$ ions increase [37]. The percentage removal of $\mathrm{Cu}(\mathrm{II})$ by different sorbents were found to increase with increasing sorbent dose. The percentage removal is increased from $18.4 \%$ to $37.8 \%$ in case of CA, $14.9 \%$ to $57.4 \%$ for CA-NMO, $9.8 \%$ to $74.5 \%$ for g-CAEN-NMO, $11.8 \%$ to $76.5 \%$ for g-CA-DETA-NMO, $26.7 \%$ to $95 \%$ for g-CATETA-NMO and 29.4 to 95.1 for g-CA-TEPA-NMO, as the adsorbent dose is increased from $5-100 \mathrm{mg}$. This behavior is due to the availability of higher binding sites and greater surface area for removal of $\mathrm{Cu}$ (II) metal ion with increasing the sorbent dosage $(17,18)$. The removal of $\mathrm{Cu}(\mathrm{II})$ had small increase in higher adsorbent dosage (above $100 \mathrm{mg}$ ).

\section{Adsorption isotherm}

The adsorption isotherm is a dynamic balance describing the equilibrium process between metal ions and solid surface of an adsorbent. Adsorption isotherm higher $q$ max was observed for larger ionic radii ions [38]. The isotherm data for the adsorption of $\mathrm{Cu}(\mathrm{II})$ ion onto CA, g-CA-EN-NMO, g-CA-DETANMO, g-CA-TETA-NMO and g-CA-TEPA-NMO adsorbents was accomplished 
by fitting to Langmuir and Freundlich models. The Langmuir isotherm and its linearized form, that assume a reversible sorption process on the homogeneous surface forming a monolayer sorption without interactions between the adsorbed species, are represented by (Equations (2) (3)).

$$
\begin{aligned}
q_{e} & =\frac{q_{\max } b C_{e}}{1+b C_{e}} \\
\frac{C_{e}}{q_{e}} & =\frac{1}{b q_{\max }}+\frac{1}{q_{\max }} C_{e}
\end{aligned}
$$

where $q_{\mathrm{e}}\left(\mathrm{mg} \cdot \mathrm{g}^{-1}\right)$ is the equilibrium concentration of metal ions on the adsorbent surface, $q_{\max }\left(\mathrm{mg} \cdot \mathrm{g}^{-1}\right)$ is the maximum adsorption capacity, $C_{\mathrm{e}}\left(\mathrm{mg} \cdot \mathrm{L}^{-1}\right)$ is the liquid phase equilibrium concentration of metal ions and $b\left(\mathrm{~L} \cdot \mathrm{mg}^{-1}\right)$ is the affinity constant.

The Freundlich isotherm and its linearized form are represented by (Equations (4) (5)). This model is an empirical equation that assumes sorption on a heterogeneous energetic distribution of active binding sites.

$$
\begin{gathered}
q_{e}=K_{f} C^{1 / n} \\
\log q_{e}=\log K_{f}+\frac{1}{n} \log C_{e}
\end{gathered}
$$

where $K_{\mathrm{f}}\left(\mathrm{L} \cdot \mathrm{g}^{-1}\right)$ is the sorption capacity constant and $n$ is the sorption intensity constant.

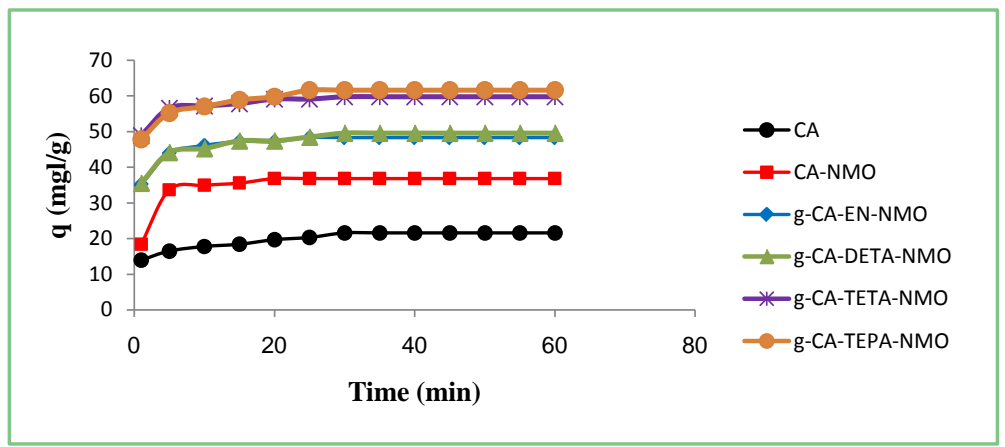

Figure 5. Effect of contact time on the removal of $\mathrm{Cu}(\mathrm{II})$.

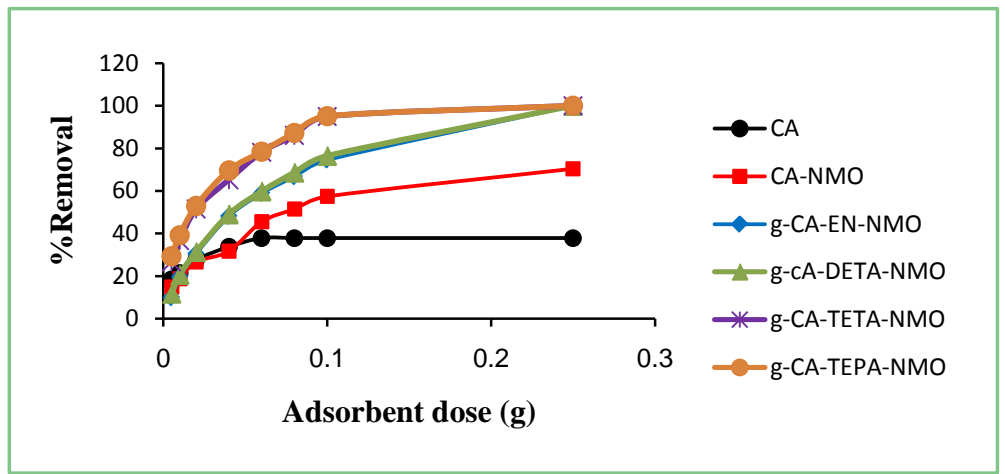

Figure 6. Effect of adsorbent dose on the removal of $\mathrm{Cu}(\mathrm{II})$. 
These two isotherm models were investigated for the removal of $\mathrm{Cu}$ (II) by using different initial metal ion volume for $30 \mathrm{~min}$ contact time and $100.0 \mathrm{mg}$ sorbent at $\mathrm{pH} 7$ and at constant temperature $25^{\circ} \mathrm{C} \pm 1^{\circ} \mathrm{C}$. The linear graphical representations of the Langmuir model for $\mathrm{Cu}(\mathrm{II})$ sorption by $\mathrm{CA}$, g-CAEN-NMO, g-CA-DETA-NMO, g-CA-TETA-NMO and g-CA-TEPA- NMO are represented in (Figure 7). The identified isotherm constants and capacity parameters, for $\mathrm{Cu}(\mathrm{II})$ are listed in (Table 1). The values of linear regression coefficients $\left(\mathrm{R}^{2}\right)$ indicate that the $\mathrm{Cu}(\mathrm{II})$ sorption processes by all sorbents are more fitted to Langmuir isotherm rather than Freundlich isotherm, which indicates that chemisorption of metals is obtained by these sorbents $(17,18)$.

Analytical applications of g-CA-EN-NMO, g-CA-DETA-NMO, g-CATETA-NMO and g-CA-TEPA-NMO for removal of $\mathrm{Cu}$ (II) ion from real water samples

Multi-stages micro-column mode was employed for removal of $\mathrm{Cu}$ (II) ion from tap, sea and industrial wastewater samples to evaluate the validity of the uses of the modified cellulose acetate sorbents g-CA-EN-NMO, g-CA-DETANMO, g-CA-TETA-NMO and g-CA-TEPA-NMO. The percentages extraction of $\mathrm{Cu}$ (II) from the real samples by these sorbents was collected in (Table 2). The removal percentage of $\mathrm{Cu}(\mathrm{II})$ ion found to be $82.9 \%$ - 91.5\% for g-CA-EN-NMO, 83.5\% - 92.9\% for g-CA-DETA-NMO, 90.2\% - 96.7\% for g-CA-TETA-NMO and $93 \%-100 \%$ for g-CA-TEPA-NMO. This is an indication on higher efficiency of sorbents towards trace $\mathrm{Cu}(\mathrm{II})$ metal ions. This reveals that the modified materials have better $\mathrm{Cu}(\mathrm{II})$ adsorption ability and offers valuable data for environmental managers and policymakers for future applications

\section{Conclusion}

The present work affords a number of environmental friendly cellulose adsorbents for the remediation of $\mathrm{Cu}(\mathrm{II})$ ion. The modified cellulose adsorbents are all

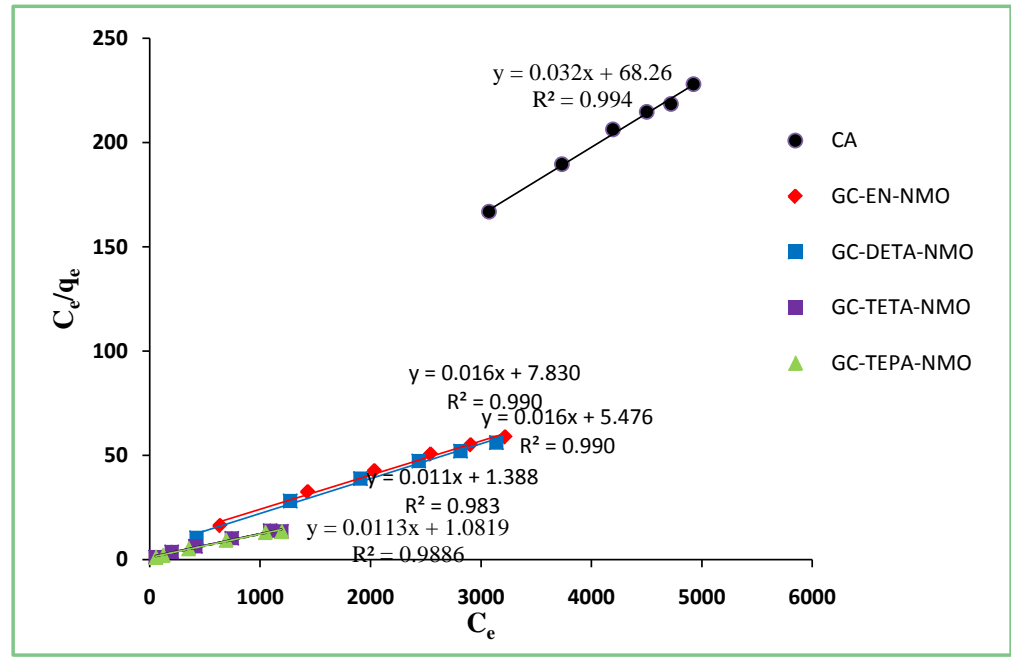

Figure 7. Langmuir isotherm for $\mathrm{Cu}(\mathrm{II})$ by $\mathrm{CA}$, g-CA-EN-NMO, g-CADETA-NMO, g-CA-TETA-NMO and g-CA-TEPA-NMO. 
Table 1. Langmuir and Freundlich isotherm constants for $\mathrm{Cu}(\mathrm{II})$ sorption.

\begin{tabular}{ccccccc}
\hline \multirow{2}{*}{ Sorbent } & \multicolumn{3}{c}{ Langmuir model } & \multicolumn{3}{c}{ Frendlich model } \\
\cline { 2 - 7 } & $q_{\max }$ & $b \times 10^{4}$ & $R^{2}$ & $K_{f}$ & $n$ & $R^{2}$ \\
\hline CA & 30.864 & 4.746 & 0.9947 & 1.124 & 2.873 & 0.9887 \\
g-CA-EN-NMO & 60.976 & 20.943 & 0.9907 & 0.924 & 4.803 & 0.9731 \\
g-CA-DETA-NMO & 59.880 & 30.504 & 0.9908 & 14.666 & 6.161 & 0.9535 \\
g-CA-TETA-NMO & 90.090 & 79.948 & 0.9831 & 17.275 & 4.560 & 0.9808 \\
g-CA-TEPA-NMO & 88.496 & 104.446 & 0.9886 & 18.998 & 4.782 & 0.9801 \\
\hline
\end{tabular}

Table 2. Percentages extraction of $\mathrm{Cu}(\mathrm{II})$ from real samples by g-CA-EN-NMO, g-CA-DETA-NMO, g-CA-TETA-NMO and g-CA-TEPA-NMO sorbents.

\begin{tabular}{ccccccc}
\hline \multirow{2}{*}{ Sample } & $1^{\text {st }}$ stage & $2^{\text {nd }}$ stage & $3^{\text {rd }}$ stage & $1^{\text {st }}$ stage & $2^{\text {nd }}$ stage & $3^{\text {rd }}$ stage \\
\cline { 2 - 6 } & \multicolumn{3}{c}{ g-CA-EN-NMO } & \multicolumn{3}{c}{ g-CA-TETA-NMO } \\
Tap water & 82.1 & 88.5 & 91.5 & 88.2 & 95.4 & 96.7 \\
Sea water & 75 & 79.1 & 82.9 & 81.3 & 89.4 & 90.2 \\
Waste water & 78.5 & 84 & 88.2 & 83.9 & 92.6 & 94.7 \\
& & g-CA-DETA-NMO & & & g-CA-TEPA-NMO \\
Tap water & 82.8 & 89.1 & 92.9 & 90.2 & 96 & 100 \\
Sea water & 75.9 & 80 & 83.5 & 85.1 & 90.5 & 93 \\
Waste water & 79.1 & 84.9 & 89 & 90.7 & 95 & 98.6 \\
\hline
\end{tabular}

characterized by higher capacity toward metal ions extraction in presence of buffering condition. Extracted cellulose was converted to CA then formed composite with NMO. The composite was surface modified with acrylamide using Fenton's reagent $\left(\mathrm{H}_{2} \mathrm{O}_{2} / \mathrm{FeSO}_{4}\right)$ then immobilized by Ethylenediamine, diethylenetriamine, triethylenetetramine and tetraethylenepentanene and was used for adsorption of $\mathrm{Cu}$ (II) from water. The sorption efficiency of these different sorbents was investigated at different conditions. The maximum sorption efficiency values were obtained at $\mathrm{pH}$ 7. The sorption equilibria were described by Langmuir and Freundlich models. The validity of the uses of these extractors was applied for the removal of $\mathrm{Cu}(\mathrm{II})$ from water, seawater and industrial wastewater.

\section{Conflicts of Interest}

The authors declare no conflicts of interest regarding the publication of this paper.

\section{References}

[1] Shriadah, M.A., Kataoka, M. and Ohzeki, K. (1985) Determination of Molybdenium (VI) in Seawater by Densitometery after Enrichment as the Tiron Complex on a Thin Layer of Anion-Exchange Resin. Analyst, 110, 125-129.

https://doi.org/10.1039/an9851000125 
[2] Shriadah, M.A., Kataoka, M. and Ohzeki, K. (1986) Determination of Iron in Seawater by Densitometery after Enrichment as a Bathophenenthroline-Disulphonate Complex on a Thin Layer of Anion-Exchange Resin. Analyst, 111, 555-558. https://doi.org/10.1039/an9861100555

[3] Shriadah, M.A. and Emara, H.I. (1991) The Distribution of Chromium, Copper, Cadmium, and Lead in Areas of Multi-Polluting Factors of Alexandria. International Proceedings Symposium of Marine Chemistry in the Arab Region, Suez, April 1991, 30-50.

[4] Shriadah, M.A. and Emara, H.I. (1996) Heavy Metals (Iron, Manganese, Nickel, Cadmium, and Lead) in the Sediments from the Easternharbor and El-Mex Bay of Alexandria, Egypt. Proceedings of 6th International Symposium: Environmental Protection Is a Must, Alexandria, 21-23 May 1996, 916-927.

[5] Shriadah, M.A. (1992) Trace Elements Concentration in Fish Samples from Alexandria Region. The Bulletin of the High Institute of Public Health, 22, 437-444.

[6] Shakweer, L., Shriadah, M.A., Fahmy, M.A. and Abdel Fattah, L. (2006) Distributions and Concentrations of Trace Elements along the Mediterranean Coastal Water of Egypt. Egyptian Journal of Aquatic Research, 32, 95-127.

[7] Abdel Ghani, S.A., Shobier, A.H., Said, T.O. and Shreadah, M.A. (2010) Organotin Compounds in Egyptian Mediterranean Sediments. Egyptian Journal of Aquatic Research, 36, 221-229.

[8] Masoud, M.S., Said, T.O., El-Zokm, G. and Shreadah, M.A. (2010) Speciation of Fe, $\mathrm{Mn}$ and $\mathrm{Zn}$ in Surficial Sediments from the Egyptian Red Sea Coasts. Chemical Speciation \& Bioavailability, 22, 257-269. https://doi.org/10.3184/095422910X12894975123773

[9] Shreadah, M.A., Abdel Ghani, S.A., Abdel Samie, A.T., Ahmed, A.M. and Hawash, H.B. (2012) Mercury and Methyl Mercury in Sediments of Northern Lakes-Egypt. Journal of Environmental Protection, 3, 254-261. https://doi.org/10.4236/jep.2012.33032

[10] Khalil, M.Kh., El Zokm, G.M., Fahmy, M.A., Said, T.O. and Shreadah, M.A. (2013) Geochemistry of Some Major and Trace Elements in Sediments of Edku and Mariut Lakes, North, Egypt. World Applied Sciences Journal, 24, 282-294.

[11] Shriadah, M.A. and Emara, H.I. (1992) Iron, Manganese, Nickel, Lead, and Cadmium in Fish and Crustacea from the Eastern Harbor and El-Mex Bay of Alexandria. The Bulletin of the High Institute of Public Health, 22, 515-525.

[12] Tayel, F.T. and Shriadah, M.A. (1996) Fe, Cu, Mn, Pb and Cd in Some Fish Species from the Western Harbor of Alexandria, Egypt. Bulletin National Institute of Oceanography\& Fisheries, Arab Republic of Egypt, 22, 85-96.

[13] Shreadah, M.A., Fahmy, M.A. and Abdel Fattah, L.A. (2015) Heavy Metals in Some Fish Species and Bivalves from the Mediterranean Coast of Egypt. Journal of Environmental Protection, 6, 1-9. https://doi.org/10.4236/jep.2015.61001

[14] Manzoor, Q., Nadeem, R., Iqbal, M., Saeed, R. and Ansari, T.M. (2013) Organic Acids Pretreatment Effect on Rosa Bourbonia Phyto-Biomass for Removal of $\mathrm{Pb}$ (II) and $\mathrm{Cu}$ (II) from Aqueous Media. Bioresource Technology, 132, 446-452. https://doi.org/10.1016/j.biortech.2013.01.156

[15] Taha, A.A., Shreadah, M.A., Heiba, H.F. and Ahmed, A.M. (2016) Multi-Component Adsorption of $\mathrm{Pb}(\mathrm{II}), \mathrm{Cd}(\mathrm{II})$, and $\mathrm{Ni}(\mathrm{II})$ onto Egyptian Na-Activated Bentonite; Equilibrium, Kinetics, Thermodynamics, and Application for Seawater Desalination. Journal of Environmental Chemical Engineering, 4, 1166-1180. https://doi.org/10.1016/j.jece.2016.01.025 
[16] Taha, A.A., Shreadah, M.A., Heiba, H.F. and Ahmed, A.M. (2017) Validity of Egyptian Na-Montmorillonite for Adsorption of $\mathrm{Pb}^{2+}, \mathrm{Cd}^{2+}$ and $\mathrm{Ni}^{2+}$ under Acidic Conditions: Characterization, Isotherm, Kinetics, Thermodynamics and Application Study. Asia-Pacific Journal of Chemical Engineering, 12, 292-306. https://doi.org/10.1002/apj.2072

[17] Yakout, A.A., El-Sokkary, R.H., Shreadah, M.A. and Abdel Hamid, O.G. (2016) Removal of $\mathrm{Cd}(\mathrm{II})$ and $\mathrm{Pb}(\mathrm{II})$ Ions from Wastewater of Different Matrices by Using Triethylenetetramine Functionalized Cellulose Acetate Crafted Copolymer-Manganese Dioxide Composite. Carbohydrate Polymers, 148, 406-414. https://doi.org/10.1016/j.carbpol.2016.04.038

[18] Yakout, A.A., El-Sokkary, R.H., Shreadah, M.A. and Abdel Hamid, O.G. (2017) Cross-Linked Graphene Oxide Sheets via Modified Extracted Cellulose with High Metal Adsorption. Carbohydrate Polymers, 172, 20-27. https://doi.org/10.1016/j.carbpol.2017.05.004

[19] Crini, G. (2005) Recent Developments in Polysaccharide-Based Materials Used as Adsorbents in Wastewater Treatment. Progress in Polymer Science, 30, 38-70. https://doi.org/10.1016/j.progpolymsci.2004.11.002

[20] Jamshaid, A., Hamid, A., Muhammad, N., Naseer, A., Ghauri, M., Iqbal, J., Rafiq, S. and Shah, N.S. (2017) Cellulose-Based Materials for the Removal of Heavy Metals from Wastewater-An Overview. ChemBioEng Reviews, 4, 1-18. https://doi.org/10.1002/cben.201700002

[21] Bicak, N., Sherrington, D.C. and Senkal, B.F. (1999) Graft Copolymer of Acrylamide onto Cellulose as Mercury Selective Sorbent. Reactive and Functional Polymers, 41, 69-76. https://doi.org/10.1016/S1381-5148(99)00021-8

[22] Chauhan, G.S., Mahajan, S. and Guleria, L.K. (2000) Polymers from Renewable Resources Sorption of $\mathrm{Cu}^{2+}$ by Cellulose Graft Copolymers. Desalination, 130, 85-88. https://doi.org/10.1016/S0011-9164(00)00076-X

[23] Chauhan, G.S., Guleria, L. and Sharma, R. (2005) Synthesis, Characterization and Metal Ion Sorption Studies of Graft Copolymers of Cellulose with Glycidyl Methacrylate and Some Comonomers. Cellulose, 12, 97-110. https://doi.org/10.1023/B:CELL.0000049349.66326.5e

[24] Hegazy, E.S.A., Kamal, H., Khalifa, N.A. and Mahmoud, G.A. (2001) Separation and Extraction of Some Heavy and Toxic Metal Ions from Their Wastes by Grafted Membranes. Journal of Applied Polymer Science, 81, 849-860. https://doi.org/10.1002/app.1504

[25] O'Connell, D.W., Birkinshaw, C. and O’Dwyer, T.F. (2008) Heavy Metal Adsorbents Prepared from the Modification of Cellulose: A Review. Bioresource Technology, 99, 6709-6724. https://doi.org/10.1016/j.biortech.2008.01.036

[26] An, B. and Zhao, D. (2012) Immobilization of As(III) in Soil and Groundwater Using a New Class of Polysaccharide Stabilized Fe-Mn Oxide Nanoparticles. Journal of Hazardous Materials, 211-212, 332-341. https://doi.org/10.1016/j.jhazmat.2011.10.062

[27] Nataraj, S.K., Roy, S., Patil, M.B., Nadagouda, M.N., Rudzinski, W.E. and Aminabhavi, T.M. (2011) Tubular Membranes for Wastewater Treatment. Desalination, 281, 348-353. https://doi.org/10.1016/j.desal.2011.08.016

[28] Abedini, R., Mousavi, S.M. and Aminzadeh, R. (2011) A Novel Cellulose Acetate (CA) Membrane Using $\mathrm{TiO}_{2}$ Nanoparticles: Preparation, Characterization, Permeation Study. Desalination, 277, 40-45. https://doi.org/10.1016/j.desal.2011.03.089

[29] Maliyekkal, S.M., Lisha, K.P. and Pradeep, T. (2010) A Novel Cellulose-Manganese 
Oxide Hybrid Material by in Situ Soft Chemical Synthesis and Its Application for the Removal of $\mathrm{Pb}$ (II) from Water. Journal of Hazardous Materials, 181, 986-995. https://doi.org/10.1016/j.jhazmat.2010.05.112

[30] Bicu, I. and Mustata, F. (2011) Cellulose Extraction from Orange Peel Using Sulfite Digestion Reagents. Bioresource Technology, 102, 10013-10019.

https://doi.org/10.1016/j.biortech.2011.08.041

[31] Siddhanta, A.K., Prasad, K., Meena, R., Prasad, G., Mehta, G.K., Chhatbar, M.U., Oza, M.D., Kumar, S. and Sanandiya, N.D. (2009) Profiling of Cellulose Content in Indian Seaweed Species. Bioresource Technology, 100, 6669-6673. https://doi.org/10.1016/j.biortech.2009.07.047

[32] Olaru, N., Olaru, L., Vasile, C. and Ander, P. (2011) Surface Modified Cellulose Obtained by Acetylation without Solvents of Bleached and Unbleached Kraft Pulps. Polimery, 56, 834-8340. https://doi.org/10.14314/polimery.2011.834

[33] Anirudhan, T.S. and Shibi, I.G. (2007) Preparation of a Cation Exchanger Containing Carboxyl Groups from Banana Stalk and Its Utilization as Chelating Agent. Infomusa, 16, 7-11.

[34] Donia, A.M., Atia, A.A. and Abouzayed, F.I. (2012) Preparation and Characterization of Nano-Magnetic Cellulose with Fast Kinetic Properties towards the Adsorption of Some Metal Ions. Chemical Engineering Journal, 191, 22-30. https://doi.org/10.1016/j.cej.2011.08.034

[35] Mahmoud, M.E. and Al-Bishri, H.M. (2011) Supported Hydrophobic Ionic Liquid on Nano-Silica for Adsorption of Lead. Chemical Engineering Journal, 166, 157-167. https://doi.org/10.1016/j.cej.2010.10.046

[36] Kosaa, S.A., Al-Zhrania, G. and Abdel Salam, M. (2012) Removal of Heavy Metals from Aqueous Solutions by Multi-Walled Carbon Nanotubes Modified with 8-Hydroxyquinoline. Chemical Engineering Journal, 181-182, 159-168. https://doi.org/10.1016/j.cej.2011.11.044

[37] Mahmoud, M.E., Yakout, A.A., El Aziz, M.T., Osman, M.M. and Abdel-Fattah, T.M. (2015) A Novel Cellulose-Dioctyl Phthate-Baker's Yeast Biosorbent for Removal of $\mathrm{Co}(\mathrm{II}), \mathrm{Cu}(\mathrm{II}), \mathrm{Cd}(\mathrm{II}), \mathrm{Hg}(\mathrm{II})$ and $\mathrm{Pb}(\mathrm{II})$. Journal of Environmental Science and Health, Part A, 50, 1072-1081. https://doi.org/10.1080/10934529.2015.1038184

[38] Zhou, D., Zhang, L., Zhou, J. and Guo, S. (2004) Cellulose/Chitin Beads for Adsorption of Heavy Metals in Aqueous Solution. Water Research, 38, 2643-2650. https://doi.org/10.1016/j.watres.2004.03.026 